$14^{\text {th }}$ Conf. Agric. Develop. Res., Fac. of Agric., Ain Shams Univ.,

March, 2019, Cairo, Egypt

Special Issue, 27(1), 635 - 648, 2019

Website: http://strategy-plan.asu.edu.eg/AUJASCI/

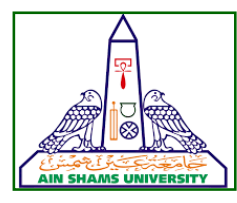

\title{
ESTIMATE OF SOME GENETIC PARAMETERS FOR SOME VEGETATIVE AND YIELDING TRAITS IN COMPLETE DIALLEL CROSSES AMONG FIVE INBRED LINES OF CUCUMBER
}

\author{
Gad Alla, O.A.M. ${ }^{*}$ El-Miniawy, S.M., Abd El-Hady, S.A. and El-Oksh, I.I. \\ Horticulture Dept., Fac. of Agric., Ain Shams Univ., P.O. Box 68, Hadayek Shubra 11241, \\ Cairo, Egypt
}

${ }^{*}$ Corresponding author: omar.abd-alla@hytechseed.com

Received 22 September, 2018, Accepted 14 October, 2018

\begin{abstract}
This experiment was implemented in the experimental farm of (Misr hytech seed co. Giza, Egypt) during winter growing seasons 2014 and 2015 to evaluate the inheritance of some cucumber vegetative and yielding traits using a complete diallel cross among five inbred lines. The results showed that the mean square of genotypes, parental inbred lines, crosses and parent vs crosses were significant for the studied traits. The hybrids $\mathrm{P}_{2} \times \mathrm{P}_{4}$ and $\mathrm{P} 2 \mathrm{xP} 5$ exhibited a useful heterosis relative to $\mathrm{Mp}$ and $\mathrm{Bp}$ for the fruit yield per plant and number of leaves per plant. The mean square of general and specific combining ability was significant for the studied traits. The higher GCA/SCA ratio than the unity of the studied traits indicating to the greatest role of the additive gene action in the expression of these traits. The inbred lines P1 and P 2 exhibited significant positive $\hat{g}_{i}$ effects in the traits of number of fruit per plant and fruit yield per plant, so these inbred lines could be act as a good combiner for developing high yielding genotypes. The $\mathrm{F} 1$ hybrids $\mathrm{P}_{1} \times \mathrm{P}_{3}, \mathrm{P}_{2} \times \mathrm{P}_{4}, \mathrm{P}_{2} \times \mathrm{P}_{5}$ and $\mathrm{P}_{4} \times \mathrm{P}_{5}$ as well as the reciprocal hybrids $\mathrm{P}_{4} \times \mathrm{P}_{1}, \mathrm{P}_{4} \times \mathrm{P}_{2}, \mathrm{P}_{4} \times \mathrm{P}_{3}$ and $\mathrm{P}_{5} \times \mathrm{P}_{3}$ recorded a significant positive $\hat{S}_{i j}$ effect but the reciprocal hybrids recorded a significant rij effect. The results revealed to more than one hybrid distinct in some traits that could be utilized in the greenhouse cucumber cultivation and the future breeding programs.
\end{abstract}

Keywords: Cucumber, Heterosis, Potence ratio, Combining ability, Gene additive.

\section{INTRODUCTION}

Cucumber Cucumis sativus $\mathrm{L}$. is a prime member of the cucurbits family which is one of the largest families of vegetable crops. Globally, cucumber is ranked as the fourth crop following tomato, onion and cabbage (Pitrat et al 1999). In Egypt, cucumber is cultivating in open field and protected cultivation in low tunnels and greenhouses. The total cultivated area with cucumber in 2016 was 23.370 ha with a productivity of 495.982 tons approximately (FAO, 2015) at rate 9.53 tons/fed. The area of greenhouses cultivated by cucumber reached about 2 million $\mathrm{m}^{2}$ approximately 5887 plastic houses, with a productivity of $9.71 \mathrm{~kg} / \mathrm{m}^{2}$.

Egyptian cucumber cultivation needs about 25 to 35 million seed in the winter season which priced 2 to $2.5 \mathrm{LE} /$ seed 1 to $1.5 \$$ per10 seeds (Personal communication). Most of these seeds are imported, the higher price of the imported cucumber seeds reflects the higher cost of production and thence reduced the farmer's profit. So that, production of local crosses of cucumber may reduce the high production cost through providing farmers with local low price crosses and more adapted to Egyptian environmental conditions.

The limited increase in crop yield could be achieved via good agricultural practices or agronomic events but the real increase is achieved via breeding targeted the higher yield. Conservation and utilization of the available crop genetic resources are the key factors to fulfill and meet the needs of the environment and both present and future generations. The demand for such genetic resources is dynamic and unpredictable. So that, 
the more conservation and availability of diversity in the future, the better are the chances for fulfilling future demand (Engels et al 1996). Yield is the most important trait in cucumber breeding programs along with agronomical performance like earliness, growth habit and fruit quality.

To establish a sound basis for any breeding program, aimed at achieving high yield, breeders must have information on the nature of combining ability of parents, their behavior and crosses combination performance (Chawla and Gupta, 1984 and El-Hosary et al (2011). Lonnquit and Gardner (1961) and El-Hosary (2014) illustrated that diallel analysis technique is the choice of providing such detailed genetic information for selecting breeding materials that show great promise for success. The combining abilitiy types if general GCA or specific SCA were defined by Sprague and Tatum (1942) and El-Hosary et al (2018). Also, the diallel cross is a useful tool to produce promising crosses and to study the heterotic effects of these crosses over their respective parents. On the same context, combining ability helps to identify the best parents and provide sufficient genetic information on the inheritance of traits. In this regard, highly general and specific combining abilities effects leading to high heterosis (Olfati et al 2012, Golabadi et al 2015 and Sedhom et al 2007).

This work aimed to investigate the impact of crossing between five selected inbred lines in complete diallel procedure and evaluate the produced F1 crosses via estimate the GCA and the SCA of parents and crosses combinations as well as heterosis in the $\mathrm{F} 1$ crosess over both the mid and the better parents.

\section{MATERIALS AND METHODS}

\section{Plant materials:}

Five inbred lines of cucumber named AVCU011001 (P1), HTCU111 (P2), HTCU416 (P3), HTCU682 (P4) and HTCU621 (P5) were subjected for this investigation based on a wide range of morphological diversity in their characters. The pedigree and origin of the five inbred lines are shown in Table 1.

\begin{tabular}{|c|c|c|c|}
\hline Name & Pedigree & Genotype & Origin* \\
\hline P1 & AVCU011001 & Beit Alpha & Taiwan \\
\hline P2 & HTCU111 & Beit Alpha & Egypt \\
\hline P3 & HTCU416 & Short Asian & Egypt \\
\hline P4 & HTCU682 & Medium Asian & Egypt \\
\hline P5 & HTCU621 & Beit Alpha & Egypt \\
\hline
\end{tabular}

*Deferent breeding programs from both Misr hytech seed and the World Vegetable Center in Taiwan AVCU. P1 inbred line from Agriculture vegetable center Taiwan and P2, P3, P4 \& P5 from Misr hytech seed co. Egypt.

\section{Hybridization}

Cucumber seeds of the inbred lines were sown on the $10^{\text {th }}$ of September during the winter season of 2013-2014 in the nursery then transplanted after 20 days in a greenhouse for accomplishing the crosses in the experimental farm of germplasm preservation laboratory of research station of Misr HYTECH Seed International Company, Giza Governorate, Egypt. Hybridizations were carried out between the five lines parental line and were utilized in a complete diallel crosses mating design to estimate general combining ability (GCA) and specific combining ability (SCA). In addition, the variances of reciprocal effect ( $r$ ) could be also obtained. The procedure of this analysis was described by Griffing (1956) method 1, model I. The estimates of GCA Variance $(\delta 2 \mathrm{~g})$ and SCA variance $(\delta 2 \mathrm{~s})$ could be expressed in terms of genetic variances according to Matzingar \& Kempthome (1956) and Cockerham (1963). The crossed fruits were harvested soon after ripening. The fruits were cut crosswise and the seeds were scrapped out and cleaned using running tap water. Seeds were dried under indirect sunlight and kept in paper bags then stored in the fridge at $10^{\circ} \mathrm{C}$ and $50 \% \mathrm{RH}$ until using it again. The seedlings were transplanting in light black soil and drip irrigation from the Nile water directly.

\section{Experimental design}




\section{Estimate of Some Genetic Parameters for Some Vegetative and Yielding Traits in Complete Diallel Crosses among Five Inbred Lines of Cucumber}

Seeds of the five parent lines and the twenty produced $\mathrm{F} 1$ crosses from these parents were sown in the nursery then transplanted on the $10^{\text {th }}$ of September during the 2014-2015 season then transplanted after 20 days in the greenhouse. The transplants of the parents and F1 crosses were arranged in a randomized complete block design in three replications. Each replicate involved 25 plot, each plot was planted by 10 plants which represent one genotype. Each experimental unit was planned to cover an area of $5 \mathrm{~m}^{2}$ including one row of $5 \mathrm{~m}$ long and $1 \mathrm{~m}$ wide, with row spacing averaged $50 \mathrm{~cm}$ apart. All agricultural practices were carried out as recommended by the Egyptian Agriculture Ministry for cucumber greenhouse cultivation.

\section{Data recorded}

A random sample of five plants of each genotype was submitted to collect the data of plant traits which were plant length (measured starting from the ground level to the apical meristem of the stem,) number of leaves/plant, number of days to first harvest, number of fruits/plant, average fruit weight, total yield/plant and total soluble solids of the fruit juice (TSS).

Statistical analysis: The obtained data were statistically analyzed according to the procedure of Gomez and Gomez (1984). The means were compared using Duncan's multiple range test (L.S.R) at 0.05 level of probability Waller and Duncan (1969).

\section{Genetic parameters}

Heterosis percentages, relative to the mid and better parents, heterosis for the studied traits was calculated using diallel software program according to Mather and Jinks (1971) as follows:

$$
\begin{aligned}
& \text { Mid - parent heterosis }(\%)=\frac{F_{1}-\mathbf{M P}}{M P} \times 100 \\
& \text { Better - parent heterosis }(\%)=\frac{F_{1}-B P}{B P} \times 100
\end{aligned}
$$

Where: $\mathrm{F} 1=$ mean value of the particular hybrid, M.P. = mean value of the two parents for that hybrid $\mathrm{P} 1+\mathrm{P} 2 \div 2$, and B.P. = better parent mean value for that hybrid.

General combining ability (GCA) and specific combining ability (SCA), were estimated by the following Model-I Method I described by
Griffing (1956) using Diallel software program. The GCA/SCA variance ratio was computed by the same program.

Hybrid potence ratio, potence ratio was estimated according to Smith (1952) to measure the degree of the trait dominance as follows:

$$
P=\frac{F_{1}-M P}{0.5 x\left(P_{2}-P_{1}\right)} \times 100
$$

Where $\mathbf{P}$ : relative potence of gene set, $\mathbf{F}_{1}$ : first generation mean, $\mathbf{P 1}$ : the mean of the least parent, P2: the mean of the higher parent, and M.P.: midparents value $=\mathrm{P} 1+\mathrm{P} 2 \div 2$. Complete dominance was indicated when $\mathbf{P}= \pm 1$; while partial dominance is indicated when "P" is between -1 and +1 , except the zero value which indicates the absence of dominance. Over dominance was considered when potence ratio value exceeds +1 . Positive and negative signs indicate the direction of the dominance of either parent.

\section{RESULTS AND DISCUSSION}

The analysis of variance of all sources of variation for the studied traits, i.e. plant length, number of leaves per plant, number of days to first harvest, number of fruits per plant, average fruit weight, fruit yield per plant and total soluble solids of the fruit flesh juice are presented in Table 2.

The mean square values of all studied traits for the genotypes and parents appeared to be a highly significant, indicating a presence of true differences among the genotypes, performance under this study for GCA. The mean square values of the crosses showed a highly significant differences among each of all studied traits for SCA. Generally, the significant differences among parent mean performances for all studied traits was expected so due to their differentiation in the pedigree and origin (Table, 1). The significant of crosses mean squares enabling to choose and utilize the highest genotypes in the studied traits. Also, the variation due to parents vs. crosses was highly significant for all the characters except the number of days to the first harvest indicating a significant heterotic response. Results indicated significant differences among the genotypes for all the traits under the study. Similar results were reported by Olfati et al (2012), Kumar et al (2013), Sandeep et al (2013) and Golabadi et al (2015) who indicated that their differences may due to using different genetic materials and genetically analysis methods. 



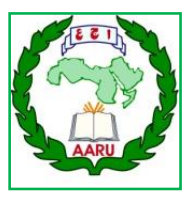

$14^{\text {th }}$ Conf. Agric. Develop. Res., Fac. of Agric., Ain Shams Univ., March, 2019, Cairo, Egypt

Special Issue, 27(1), 635 - 648, 2019

Website: http://strategy-plan.asu.edu.eg/AUJASCl/

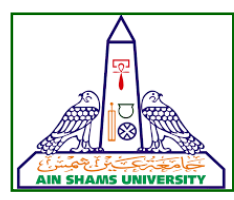

Table 2. Analysis of mean square values of the studied traits for F1 crosses

\begin{tabular}{|c|c|c|c|c|c|c|c|c|}
\hline s.o.v. & d.f. & 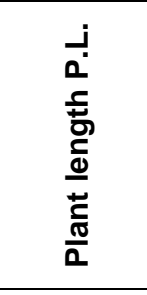 & 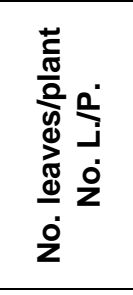 & 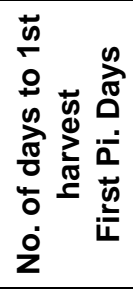 & 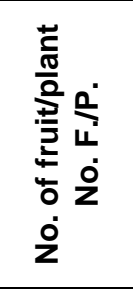 & 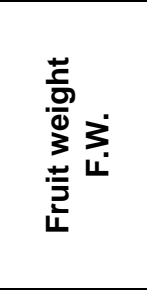 & 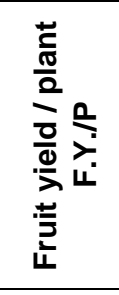 & مُ \\
\hline Rep. & 2 & 136.333 & 7.84 & 2.093 & 2.427 & 65.187 & 0.064 & 0.001 \\
\hline Genotypes & 24 & $2791.47^{\star *}$ & $27.880^{* *}$ & $37.137^{* *}$ & $56.521^{* *}$ & $348.793^{* *}$ & $0.595^{\star \star}$ & $0.398^{* *}$ \\
\hline Parents & 4 & $4955.83^{* *}$ & $48.43^{* *}$ & $84.00^{* *}$ & $71.17^{* *}$ & $287.70^{* *}$ & $0.44^{\star *}$ & $0.83^{* *}$ \\
\hline Crosses & 19 & $2080.07^{\star *}$ & $22.01^{* *}$ & $29.13^{\star *}$ & $55.89^{\star *}$ & $339.74^{\star *}$ & $0.62^{\star \star}$ & $0.31^{* *}$ \\
\hline $\begin{array}{l}\text { Parent vs } \\
\text { Crosses }\end{array}$ & 1 & $7650.75^{\star *}$ & $57.20^{* *}$ & 1.76 & $9.91^{*}$ & $765.28^{\star *}$ & $0.67^{* *}$ & $0.28^{\star *}$ \\
\hline Error & 48 & 131.47 & 4.92 & 10.30 & 2.32 & 86.84 & 0.06 & 0.01 \\
\hline GCA & 4 & $2707.69^{* *}$ & $6.08^{* *}$ & $17.12^{* *}$ & $40.65^{\star *}$ & $272.95^{\star *}$ & $0.38^{* *}$ & $0.38^{* *}$ \\
\hline SCA & 10 & $841.63^{\star *}$ & $11.67^{* *}$ & $11.33^{* *}$ & $5.25^{\star \star}$ & $64.70^{*}$ & $0.07^{* *}$ & $0.07^{\star \star}$ \\
\hline Reciprocal & 10 & $308.47^{\star *}$ & $8.21^{* *}$ & $11.53^{\star *}$ & $23.70^{\star \star}$ & $105.15^{\star *}$ & $0.25^{* *}$ & $0.10^{\star \star}$ \\
\hline Error & 48 & 43.82 & 1.64 & 3.43 & 0.77 & 28.95 & 0.02 & 0.00 \\
\hline GCA/SCA & & 3.22 & 0.52 & 1.51 & 7.74 & 4.22 & 5.36 & 5.41 \\
\hline
\end{tabular}

* and ${ }^{* *}$ : significant and highly significant at 0.05 and 0.01 probability level, respectively.

\section{Mean performances}

Data on the number of fruits per plant, showed that parent P1 yielded more fruits (23.67 fruits) compared to the parents P2 and P5 which yielded 16.67 and 13.67 fruits, respectively. Results referred that the crosses P3 X P1 exhibited the highest number of fruit per plant (24.40) followed by P2 X P4 and P2 X P1 which produced the same number of fruits (22.33).

Concerning of fruit weight, Table 3 showed that P4 recorded the heaviest fruit $(106.5 \mathrm{gm}) \mathrm{com}$ pared to P5 which recorded $80.69 \mathrm{~g}$ fruit weight. The obtained results clarified that the crosses $\mathrm{P} 4 \mathrm{X}$ P1, P3 X P4, P2 X P5, P2 X P1, P4 X P2 and P4 X $P 2$ recorded the heaviest fruit weight (120.9, $112.5,108.9,108.9,108.7$, and $107.7 \mathrm{gm}$ respectively).
As for total yield per plant Table $\mathbf{3}$ showed that P1 produced a significantly the highest fruit yield per plant $(2.040 \mathrm{~kg})$ compared to the other parents. The crosses P2 X P1 and P2 X P4 produced the highest fruit yield per plant, $(2.430$ and $2.420 \mathrm{~kg}$, respectively), compared to the rest of crosses.

Respecting total soluble solids percent in fruit juice, P3 exhibited the significant highest TSS (3\%) compared to the other parents. Whereas the cross P4 X P3 gave the highest fruit juice TSS (3.180\%).

Days to marketable maturity, number of marketable fruits per plant, total soluble solids have a wide variation due to the variety of horticultural characters reported by these data are in agreement with Gharib (1991), Darwish (1992), ElMahdy et al (1992) Singh et al (2002), Das et al (2003), Verma (2003), Wadid et al (2003), Kumar (2006), Munshi et al (2007), Kumar et al (2008), Hanchinamani et al (2008), Yogesh et al (2009) 
639 Estimate of Some Genetic Parameters for Some Vegetative and Yielding Traits in Complete Diallel Crosses among Five Inbred Lines of Cucumber

and Kumar et al (2013) for these characters in cucumber.

Table 3. The mean performances of the parent, $F_{1}$ crosses and reciprocal crosses for studied characters

\begin{tabular}{|c|c|c|c|c|c|c|c|}
\hline genotypes & 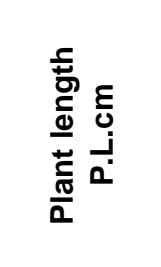 & 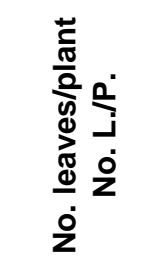 & 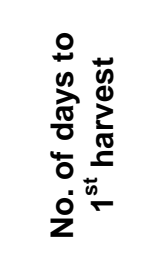 & 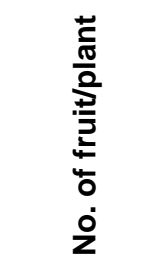 & $\begin{array}{l}E \\
5 \\
5 \\
\frac{E}{0} \\
\frac{0}{0} \\
3 \\
\frac{1}{2} \\
\frac{2}{4}\end{array}$ & 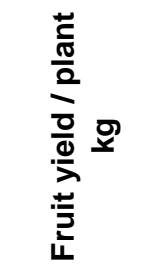 & $\begin{array}{l}\stackrel{0}{ } \\
\text { ஸे } \\
\text { ஸे }\end{array}$ \\
\hline \multicolumn{8}{|l|}{ Parents } \\
\hline P1 & $175.0 \mathrm{~L}$ & $30.67 \mathrm{C}-\mathrm{F}$ & 32.001 & $23.67 \mathrm{AB}$ & $86.34 \mathrm{H}-\mathrm{J}$ & $2.040 \mathrm{BC}$ & $2.080 \mathrm{M}$ \\
\hline P2 & $133.3 \mathrm{M}$ & $20.00 \mathrm{M}$ & 32.001 & $16.67 \mathrm{~F}-\mathrm{H}$ & $86.77 \mathrm{H}-\mathrm{J}$ & $1.440 \mathrm{~F}-\mathrm{I}$ & 1.8300 \\
\hline P3 & $230.0 \mathrm{EF}$ & 28.33 F-J & $43.00 \mathrm{~A}$ & $13.00 \mathrm{lJ}$ & 90.63 F-J & $1.180 \mathrm{IJ}$ & $3.000 \mathrm{C}$ \\
\hline P4 & 221.7 FG & 27.67 G-K & $36.00 \mathrm{E}-\mathrm{H}$ & $11.33 \mathrm{KL}$ & 106.5 B-D & $1.210 \mathrm{IJ}$ & $2.850 \mathrm{E}$ \\
\hline P5 & $216.7 \mathrm{GH}$ & $26.00 \mathrm{~J}-\mathrm{L}$ & $42.00 \mathrm{AB}$ & 13.67 I & $80.69 \mathrm{~J}$ & $1.100 \mathrm{JK}$ & $2.030 \mathrm{MN}$ \\
\hline \multicolumn{8}{|l|}{ Crosses } \\
\hline $\mathrm{P} 1 \times \mathrm{P} 2$ & $178.3 \mathrm{~L}$ & $26.67 \mathrm{I}-\mathrm{L}$ & $37.00 \mathrm{D}-\mathrm{G}$ & 17.20 E-H & 89.14 G-J & $1.530 \mathrm{E}-\mathrm{H}$ & $2.420 \mathrm{IJ}$ \\
\hline $\mathrm{P} 1 \times \mathrm{P} 3$ & 201.7 I-K & $25.67 \mathrm{KL}$ & $38.00 \mathrm{C}-\mathrm{F}$ & $17.40 \mathrm{E}-\mathrm{G}$ & 94.56 E-I & $1.670 \mathrm{D}-\mathrm{F}$ & $2.400 \mathrm{lJ}$ \\
\hline $\mathrm{P} 1 \times \mathrm{P} 4$ & 241.7 CD & $27.00 \mathrm{H}-\mathrm{L}$ & 38.67 B-F & $20.51 \mathrm{D}$ & 102.6 B-E & $2.110 \mathrm{BC}$ & $2.270 \mathrm{~K}$ \\
\hline $\mathrm{P} 1 \times \mathrm{P} 5$ & $193.3 \mathrm{~K}$ & $28.00 \mathrm{G}-\mathrm{K}$ & $41.00 \mathrm{~A}-\mathrm{C}$ & $12.67 \mathrm{I}-\mathrm{K}$ & 90.77 F-J & $1.140 \mathrm{JK}$ & $2.420 \mathrm{IJ}$ \\
\hline $\mathrm{P} 2 \times \mathrm{P} 3$ & $213.3 \mathrm{G}-\mathrm{I}$ & $25.00 \mathrm{~L}$ & $34.00 \mathrm{G}-\mathrm{I}$ & $18.55 \mathrm{E}$ & $87.53 \mathrm{H}-\mathrm{J}$ & $1.620 \mathrm{D}-\mathrm{F}$ & $1.950 \mathrm{~N}$ \\
\hline $\mathrm{P} 2 \times \mathrm{P} 4$ & $245.0 \mathrm{C}$ & $29.33 \mathrm{D}-\mathrm{H}$ & $34.00 \mathrm{G}-\mathrm{I}$ & $22.33 \mathrm{BC}$ & 107.7 BC & $2.420 \mathrm{~A}$ & $2.400 \mathrm{IJ}$ \\
\hline $\mathrm{P} 2 \times \mathrm{P} 5$ & 233.3 DE & 31.67 B-D & $32.67 \mathrm{HI}$ & $17.11 \mathrm{E}-\mathrm{H}$ & $108.9 \mathrm{BC}$ & $1.870 \mathrm{CD}$ & $2.170 \mathrm{~L}$ \\
\hline $\mathrm{P} 3 \times \mathrm{P} 4$ & $216.7 \mathrm{GH}$ & 31.67 B-D & $35.67 \mathrm{~F}-\mathrm{H}$ & $13.33 \mathrm{IJ}$ & $112.5 \mathrm{AB}$ & $1.500 \mathrm{E}-\mathrm{H}$ & $2.330 \mathrm{JK}$ \\
\hline P3 x P5 & $215.0 \mathrm{GH}$ & 28.67 E-I & 39.33 B-E & $18.42 \mathrm{E}$ & $85.10 \mathrm{IJ}$ & $1.570 \mathrm{E}-\mathrm{G}$ & $2.820 \mathrm{E}$ \\
\hline $\mathrm{P} 4 \times \mathrm{P} 5$ & $263.3 \mathrm{AB}$ & $30.67 \mathrm{C}-\mathrm{F}$ & $35.67 \mathrm{~F}-\mathrm{H}$ & $15.80 \mathrm{GH}$ & $99.69 \mathrm{C}-\mathrm{F}$ & $1.580 \mathrm{E}-\mathrm{G}$ & $2.680 \mathrm{G}$ \\
\hline \multicolumn{8}{|c|}{ Reciprocal crosses } \\
\hline $\mathrm{P} 2 \times \mathrm{P} 1$ & $176.7 \mathrm{~L}$ & $25.67 \mathrm{KL}$ & $34.00 \mathrm{G}-\mathrm{I}$ & $22.33 \mathrm{BC}$ & $108.9 \mathrm{BC}$ & $2.430 \mathrm{~A}$ & $2.470 \mathrm{HI}$ \\
\hline $\mathrm{P} 3 \times \mathrm{P} 1$ & $193.3 \mathrm{~K}$ & $26.67 \mathrm{I}-\mathrm{L}$ & 32.001 & $24.40 \mathrm{~A}$ & $88.38 \mathrm{H}-\mathrm{J}$ & $2.160 \mathrm{~B}$ & $2.980 \mathrm{C}$ \\
\hline $\mathrm{P} 4 \times \mathrm{P} 1$ & $251.7 \mathrm{C}$ & $32.33 \mathrm{BC}$ & $40.33 \mathrm{~A}-\mathrm{D}$ & $11.00 \mathrm{~L}$ & $120.9 \mathrm{~A}$ & $1.330 \mathrm{G}-\mathrm{J}$ & $2.830 \mathrm{E}$ \\
\hline P5 x P1 & 210.0 G-J & $28.00 \mathrm{G}-\mathrm{K}$ & $34.00 \mathrm{G}-\mathrm{I}$ & $21.46 \mathrm{CD}$ & 100.6 C-F & $2.160 \mathrm{~B}$ & 2.720 FG \\
\hline $\mathrm{P} 3 \times \mathrm{P} 2$ & $221.7 \mathrm{FG}$ & 31.67 B-D & $40.67 \mathrm{~A}-\mathrm{C}$ & $13.20 \mathrm{lJ}$ & $96.58 \mathrm{D}-\mathrm{H}$ & $1.290 \mathrm{H}-\mathrm{J}$ & $2.350 \mathrm{JK}$ \\
\hline $\mathrm{P} 4 \times \mathrm{P} 2$ & $253.3 \mathrm{BC}$ & $33.67 \mathrm{~A}$ & 36.33 E-G & $11.75 \mathrm{~J}-\mathrm{L}$ & 108.7 BC & $1.280 \mathrm{H}-\mathrm{J}$ & $2.530 \mathrm{H}$ \\
\hline $\mathrm{P} 5 \times \mathrm{P} 2$ & $213.3 \mathrm{G}-\mathrm{I}$ & $26.67 \mathrm{I}-\mathrm{L}$ & $41.00 \mathrm{~A}-\mathrm{C}$ & 18.00 EF & $94.08 \mathrm{E}-\mathrm{I}$ & $1.710 \mathrm{D}-\mathrm{F}$ & $2.030 \mathrm{MN}$ \\
\hline $\mathrm{P} 4 \times \mathrm{P} 3$ & $266.7 \mathrm{~A}$ & 29.67 D-G & 32.001 & $11.18 \mathrm{KL}$ & $81.87 \mathrm{~J}$ & $0.9100 \mathrm{KL}$ & $3.180 \mathrm{~B}$ \\
\hline $\mathrm{P} 5 \times \mathrm{P} 3$ & 211.7 G-J & 31.00 C-E & $40.33 A-D$ & $9.200 \mathrm{M}$ & $85.78 \mathrm{IJ}$ & $0.7900 \mathrm{~L}$ & $2.370 \mathrm{IJ}$ \\
\hline $\mathrm{P} 5 \times \mathrm{P} 4$ & 211.7 G-J & $24.67 \mathrm{~L}$ & $35.67 \mathrm{~F}-\mathrm{H}$ & $15.67 \mathrm{H}$ & 99.24 C-G & $1.570 \mathrm{E}-\mathrm{G}$ & $2.950 \mathrm{CD}$ \\
\hline
\end{tabular}

\section{Combining abilities}

The analyses of general and specific combining ability differ for all studied characters are present in Table 2. The mean squares of both general and specific combining ability were significant for all traits. The mean squares of reciprocal were highly significant for all studied traits, indicating that the maternal effect is absent in the studied traits. When both general and specific combining ability 
mean squares are significant, this defines which type and/or types of gene action are important in the performance of single-cross progeny. To overcome such situation the size of mean squares can be used to assume the relative importance of both types of combining ability. Hence, GCA/SCA ratio was used for measuring the genetic variance nature. When the ratio of GCA/SCA was exceeded for all studied traits this means that the additive and non-additive types of gene action have a greater importance in the inheritance of these traits. Therefore, it is evident for improving the yield and yield components. Also, selection procedures based on the accumulation of additive effect may be successful in improving all the studied traits. Average fruit weight, fruit length, total soluble solids, number of marketable fruits per plant and days to marketable maturity. Similar results were reported by Singh (1997), Yogesh et al (2009) and Kumar et al (2013).

General, specific and reciprocal combining ability effects

\section{General combining ability effects}

Data of general combining ability effects for individual parental genotype in each trial are presented in Table 4. General combining ability effects computed herein differed significantly for all traits. High positive values would be interest under all studied traits except number of days to the first harvest which recorded high negative values that would be useful for the breeder's point of view. The parental inbred lines 1 and 2 exhibited significant positive effects for the number of fruits per plant and fruit yield/plant, indicating that these inbred lines could be considered a good combiner for developing high yield genotypes. But, they have undesirable effects on other traits.

The parental inbred line P3 seemed to be a good combiner for the number of days to the first harvest, and TSS\% but it expressed significant undesirable or insignificant effects for the remain traits. The parental inbred line P4 showed a significant desirable effect for all traits except the number of fruits per plant and fruit yield per plant. Therefore, this parent can be used to improve fruit quality. The parental inbred line P5 seemed to be the best combiner for the number of days to the first harvest. However, it gave undesirable effects for other traits. This parent can be used for transfer earliness trait because it contains additive gene effect controlled this trait.

\section{Specific combining ability effects and recipro- cal effects}

Specific combining ability and reciprocal effects of the parental combinations were estimated for the twenty crosses only when significant mean squares were obtained in Table 4. Plant height of $\mathrm{F} 1$ crosses $\mathrm{P} 1 \times \mathrm{P} 4, \mathrm{P} 2 \times \mathrm{P} 3, \mathrm{P} 2 \times \mathrm{P} 4$ and $\mathrm{P} 2 \times \mathrm{P} 5$ and two reciprocal crosses P5xP2 and P5xP4 exhibited highly significant positive desirable effects and reciprocal effects, respectively. While negative and or insignificant effects were detected for respect crosses. With regard to the number leaves/plant, the two $\mathrm{F} 1$ crosses $\mathrm{P} 2 \times \mathrm{P} 4$ and P2xP5 as well as the two reciprocal crosses P5xP2 and P5XP4 exhibited the highest desirable effects and reciprocal effects, respectively. With regard to the number of days to the first harvest, the $\mathrm{F} 1$ cross P3xP4, P2xP1, P3xP1 and P5xP1 showed significant negative effects and reciprocal effects, respectively.

Data in Table 3 displayed the mean performances of some economic traits, i.e. plant length, number of leaves per plant, number of days to first harvest, number of fruits/plant, fruit weight, fruit yield per plant and total soluble solids, for twentyfive cucumber genotypes which were 5 parental inbred lines and their ten $\mathrm{F} 1$ as well as ten reciprocal F1 crosses. The results clarified that P3 and P4 parents showed the significant taller plants, i.e. $(230 \mathrm{~cm})$ and $(221.7 \mathrm{~cm})$, respectively. Meanwhile, the P1 showed the lowest value for plant length $(175 \mathrm{~cm})$. These results are in line with that of Ram et al (1996) who found a higher variability in vine length of 21 evaluated genotypes of cucumber. The F1 crosses P4 X P5 showed the highest stem length $263.3 \mathrm{~cm}$, however, for reciprocal crosses, the P4 X P3 exhibited the highest genotype for plant length $(266.7 \mathrm{~cm})$. On the other hand, the cross P1 X P2 and its reciprocal P2xP1 showed the shortest plants $(178.3$ and $176.3 \mathrm{~cm}$, respectively).

Regarding number of days to the first harvest, the results showed that the earliest parents for harvesting were P1 and P2 (days). Meanwhile, the lateness parents were P3 and P5 (43 and 42 days). The crosses $P 3 \times P 1$ and $P 4 \times P 3$ were the earliest of harvesting, 32 days from transplanting, also, the cross P2 X P5 displayed the shorter number of days to first harvest, 32.67 days. Despite, the crosses P1 X P5, P5 X P2 and P5 X $\mathrm{P} 3$ that shared in the P5 parent, these crosses 

Complete Diallel Crosses among Five Inbred Lines of Cucumber

showed the least number of days. The first two crosses had the same days to first harvest

Table 4. Combining ability effects of 5 cucumber inbred lines and its crosses for all studied traits

\begin{tabular}{|c|c|c|c|c|c|c|c|}
\hline \multirow[b]{2}{*}{ Genotype } & \multicolumn{7}{|c|}{ Traits } \\
\hline & $\begin{array}{c}\text { Plant } \\
\text { length } \\
\text { P.L. }\end{array}$ & \begin{tabular}{|c|} 
No. \\
leaves/plant \\
No. L./P. \\
\end{tabular} & \begin{tabular}{|c|}
$\begin{array}{c}\text { No. of days } \\
\text { to } 1^{\text {st }} \\
\text { harvest }\end{array}$ \\
\end{tabular} & $\begin{array}{c}\text { No. of } \\
\text { fruit/plant }\end{array}$ & $\begin{array}{c}\text { Fruit } \\
\text { weight }\end{array}$ & $\begin{array}{l}\text { Fruit } \\
\text { yield / } \\
\text { plant }\end{array}$ & T.S.S. \\
\hline \multicolumn{8}{|l|}{ GCA Effects } \\
\hline g1 & $-15.867^{* *}$ & -0.147 & $3.0363^{* *}$ & $0.207^{\star *}$ & 0.278 & $0.277^{\star *}$ & -0.016 \\
\hline g2 & $-15.367^{* *}$ & $-1.247^{* *}$ & $0.987^{* *}$ & $0.173^{*}$ & 0.919 & $0.119^{* *}$ & $-0.284^{\star *}$ \\
\hline g3 & $4.467^{\star}$ & 0.387 & $-1.225^{\star *}$ & -0.06 & $-5.219^{\star *}$ & $-0.197^{\star *}$ & $0.156^{\star *}$ \\
\hline g4 & $23.8^{\star \star}$ & $0.82^{*}$ & $-1.969^{* *}$ & -0.093 & $8.050^{\star \star}$ & -0.074 & $0.206^{\star *}$ \\
\hline g5 & 2.967 & 0.187 & $-0.829^{* *}$ & $-0.227^{\star *}$ & $-4.027^{*}$ & $-0.126^{* *}$ & $-0.061^{* *}$ \\
\hline LSD 5\% gi & 3.76 & 0.728 & 0.5 & 0.144 & 3.055 & 0.081 & 0.033 \\
\hline LSD 1\% gi & 5.014 & 0.97 & 0.666 & 0.193 & 4.075 & 0.109 & 0.044 \\
\hline LSD 5\% gi-gj & 5.945 & 1.15 & 0.79 & 0.228 & 4.831 & 0.129 & 0.052 \\
\hline LSD 1\% gi-gj & 7.928 & 1.534 & 1.054 & 0.304 & 6.444 & 0.172 & 0.069 \\
\hline \multicolumn{8}{|l|}{ SCA Effects } \\
\hline P1 x P2 & -6.799 & -0.719 & 0.927 & -0.651 & 1.232 & 0.002 & 0.027 \\
\hline P1 x P3 & -6.633 & $-2.353^{* *}$ & -2.007 & $2.695^{\star *}$ & -0.167 & $0.247^{* *}$ & -0.073 \\
\hline P1 x P4 & $23.2^{\star \star}$ & 0.7133 & $4.26^{\star *}$ & $-1.705^{\star *}$ & $6.863^{*}$ & -0.071 & $-0.373^{*}$ \\
\hline P1 x P5 & -0.966 & -0.32 & -0.073 & $-1.540^{\star *}$ & 2.867 & -0.081 & -0.073 \\
\hline P2 x P3 & $12.866^{\star *}$ & 0.913 & 0.86 & -0.281 & -0.225 & -0.054 & -0.04 \\
\hline P2 X P4 & $25.2^{\star *}$ & $3.647^{* *}$ & 0.46 & $1.630^{* *}$ & 2.643 & $0.220^{*}$ & -0.173 \\
\hline P2 x P5 & $20.2^{\star \star}$ & $1.947^{\star}$ & -0.207 & 1.003 & $7.999^{*}$ & $0.209^{*}$ & -0.04 \\
\hline P3 x P4 & -2.133 & 1.18 & $-3.307^{* *}$ & -0.941 & -2.207 & -0.108 & -0.107 \\
\hline P3 x P5 & $-9.633^{*}$ & 0.98 & 0.36 & -0.531 & -1.895 & -0.079 & -0.14 \\
\hline P4 x P5 & -4.799 & $-1.620^{*}$ & -2.04 & $2.1376^{\star \star}$ & -1.14 & $0.188^{*}$ & -0.107 \\
\hline LSD 5\% sij & 7.751 & 1.5 & 2.17 & 1.03 & 6.3 & 0.168 & 0.298 \\
\hline LSD 1\% sij & 10.337 & 2 & 2.894 & 1.374 & 8.401 & 0.224 & 0.397 \\
\hline LSD 5\% sij-Sik & 11.889 & 2.301 & 3.328 & 1.58 & 9.663 & 0.257 & 0.457 \\
\hline LSD 1\% sij-skl & 15.856 & 3.068 & 4.439 & 2.108 & 12.887 & 0.343 & 0.609 \\
\hline LSD 5\% sij-skl & 10.29 & 1.993 & 2.882 & 1.369 & 8.368 & 0.223 & 0.395 \\
\hline \multicolumn{8}{|c|}{ Reciprocal SCA effect } \\
\hline P2 x P1 & 0.833 & 0.5 & $-2.567^{\star \star}$ & -0.167 & $-9.868^{*}$ & $-0.451^{\star \star}$ & -0.025 \\
\hline P3 x P1 & 4.167 & -0.5 & $-3.5^{\star *}$ & $-0.5^{\star *}$ & 3.092 & $-0.246^{*}$ & $-0.292^{* *}$ \\
\hline P4 x P1 & -5 & $-2.667^{\star *}$ & $4.756^{\star \star}$ & 0.167 & $-9.159^{\star}$ & $0.390^{\star *}$ & $-0.283^{* *}$ \\
\hline P5 x P1 & -8.333 & 0 & $-4.395^{\star \star}$ & 0 & -4.931 & $-0.511^{* *}$ & $-0.15^{\star *}$ \\
\hline P3 x P2 & -4.167 & $-3.333^{* *}$ & $2.675^{\star \star}$ & -0.167 & -4.525 & 0.167 & $-0.2^{* *}$ \\
\hline P4 x P2 & -.167 & $-2.167^{\star}$ & $5.292^{\star *}$ & 0 & -0.506 & $0.570^{\star \star}$ & -0.067 \\
\hline P5 x P2 & $10^{*}$ & $2.5^{\star *}$ & -0.444 & 0 & 7.391 & 0.079 & 0.067 \\
\hline P4 x P3 & $-25^{\star \star}$ & 1 & 1.075 & 0.167 & $15.332^{\star *}$ & $0.295^{\star *}$ & $-0.425^{\star *}$ \\
\hline P5 $x$ P3 & 1.667 & -1.167 & $4.608^{\star *}$ & 0 & -0.341 & $0.389^{\star *}$ & $0.225^{\star *}$ \\
\hline P5 x P4 & $25.833^{\star *}$ & $3^{* *}$ & 0.067 & 0 & 0.226 & 0.003 & $-0.133^{* *}$ \\
\hline LSD 5\% Rij & 9.4 & 1.819 & 1.249 & 0.361 & 7.639 & 0.204 & 0.082 \\
\hline LSD 1\% Rij & 12.536 & 2.426 & 1.666 & 0.481 & 10.188 & 0.271 & 0.11 \\
\hline LSD 5\% Rij-Rik & 13.293 & 2.572 & 1.767 & 0.51 & 10.804 & 0.288 & 0.116 \\
\hline LSD 1\% Rij-Rik & 2.944 & 2.944 & 2.944 & 2.944 & 2.944 & 2.944 & 2.944 \\
\hline
\end{tabular}


${ }^{*}$ and ${ }^{* *}$ : significant and highly significant at 0.05 and 0.01 probability level, respectively.

(41 days). Also, P5 X P3 and P4 X P1 had the same number of days to the first harvest $(40.33$ days). Also, the highest main number of days $\mathrm{P} 3 \mathrm{X}$ $\mathrm{P} 2$ was for the latest genotype in harvest (40.67 days from transplanting to first harvest. Parent P5 showed high general combining ability for delaying the first harvest). The gynoecious, yield was the best performing cultivar in the character of early ripening. Melisa and Wenher (2006) reported the harvest of the gynoecious have more and more concentrated slicing type monoecious cucumbers, e.g., "Dasher II.

For the number of fruit/plant, the most desirable significant positive effects and reciprocal effects were expressed by the $\mathrm{F} 1$ crosses $\mathrm{P} 1 \mathrm{xP} 3, \mathrm{P} 2 \mathrm{xP} 4$ and $\mathrm{P} 4 \mathrm{XP5}$ and reciprocal cross $\mathrm{P} 5 \mathrm{XP1}$, respectively. With regard to fruit weight, the two F1 crosses P3xP4 and P3xP4, as well as the reciprocal cross, showed significant positive effects. As for fruit yield/ plant, the four F1 crosses P1xP3, P2xP4, P2xP5 and P4xP5 as well as the reciprocal crosses P4xP1, P4xP2, P4xP3 and P5xP3 showed significant positive effects and reciprocal effects, respectively.

As for TSS\%, the $\mathrm{F} 1$ crosses P1xP2, P1xP3, $\mathrm{P} 1 \mathrm{xP5}$ and $\mathrm{P} 4 \mathrm{xP5}$ exhibited significant positive effects while the reciprocal crosses P5xP1, P4xP2, P4xP3 and P5xP4 exhibited reciprocal effects. These crosses showed a higher specific combining ability because of P4 is a good combiner. Such crosses may show desirable transgressive segregates, providing the additive genetic system by the good combiner as well as the complementary and epistatic effects present in the cross, act in the same direction to reduce undesirable plant characteristics and maximize the character in view. Therefore, the previous crosses might be of prime importance in the breeding program for traditional breeding procedures. The present results were in agreement with those reported by Gharib (1991), Darwish (1992) and Yaccop et al (1993) and Wadid et al (2003) on cucumber main stem length, Solanki and Seth (1980), Gharib (1991), Darwish (1992), Yaccop et al (1993) and Wadid et al (2003) on yield and its components of cucumber.
Heterosis effects: Parents versus crosses mean squares shown in Table 2 indicated to the average heterosis overall crosses, were found to be highly significant for all traits studied except, number of days to the first harvest. Heterosis data are presented in Table $\mathbf{5}$ and $\mathbf{6}$. Significant positive heterotic effects relative to better parents' values may be interesting for most traits under investigation. However, for the number of days to the first harvest high negative values would be useful form the breeder's point of view. Regarding the plant length values of heterotic effects ranged from 14.59 in P2 $x$ P1 to 42.73 in P4 x P2 relative to mid-parent (Mp) in crosses. On the same context, the useful heritability effects ranged from 10.53 to 18.79 in the crosses P2xP4 and P4xP5, respectively. It is worthy to notice that 12 crosses relative to the $\mathrm{Mp}$ and 6 crosses relative to best-parent $(\mathrm{Bp})$ conferred a significant positive heterotic effect for this trait.

For the number of leaves/plant, seven and two crosses exhibited significant positive heterotic effects relative to $\mathrm{Mp}$ and $\mathrm{Bp}$, respectively. The most desirable heterotic effects were detected by crosses P2xP5 and P4xP2 which gave useful heterosis relative to both $\mathrm{Mp}$ and $\mathrm{Bp}$.

For the number of days to the first harvest, the crosses tended to deviate towards earliness especially in the two reciprocal crosses $\mathrm{P} 3 \mathrm{xP} 1$ and $\mathrm{P} 4 \mathrm{xP} 3$ relative to $\mathrm{Mp}$. Meanwhile, no crosses showed negative heritability in this trait.

Regarding the number of fruit per plant, eleven crosses relative to the $\mathrm{Mp}$ and two crosses relative to the Bp expressed significant positive heterotic effects for this trait.

As for fruit weight, five and two crosses exhibited a significant positive heterotic effect relative to $\mathrm{Mp}$ and $\mathrm{Bp}$, respectively. The most desirable heterotic effects were detected by crosses P2xP5 and $\mathrm{P} 2 \mathrm{xP} 1$ which gave useful heterosis relative to $\mathrm{Mp}$ and $\mathrm{Bp}$.

For fruit yield/ plant, ten and two crosses exhibited significant positive heterotic effects relative to $\mathrm{Mp}$ and $\mathrm{Bp}$, respectively. The most desirable heterotic effects were detected by crosses P2xP4 and $\mathrm{P} 2 \mathrm{xP5}$ which gave useful heterosis relative to $\mathrm{Mp}$ and $\mathrm{Bp}$. 
643 Estimate of Some Genetic Parameters for Some Vegetative and Yielding Traits in Complete Diallel Crosses among Five Inbred Lines of Cucumber 
Table 5. Heterosis percentage relative to the mid and better-parents of the F1 crosses and its reciprocal vegetative characteristics

\begin{tabular}{|c|c|c|c|c|c|c|}
\hline \multirow[b]{2}{*}{ Genotypes } & \multicolumn{2}{|c|}{ Plant height } & \multicolumn{2}{|c|}{ No. leaves/plant } & \multicolumn{2}{|c|}{ No. of days to $1^{\text {st }}$ harvest } \\
\hline & $\mathbf{H} \% \mathbf{M p}$ & H\% Bp & $\mathrm{H} \% \mathrm{Mp}$ & $\mathrm{H} \% \mathrm{Bp}$ & $\mathrm{H} \% \mathrm{Mp}$ & H\% Bp \\
\hline P1 x P2 & $15.68^{\star *}$ & 1.905 & -5.263 & $-13.043^{*}$ & $-15.625^{\star}$ & 15.625 \\
\hline P1 x P3 & -0.41 & $-12.319^{* *}$ & $12.994^{*}$ & $-16.304^{* *}$ & -1.333 & $18.75^{\star}$ \\
\hline P1 $\times$ P4 & $21.85^{\star \star}$ & $9.023^{*}$ & 4.706 & $-11.957^{*}$ & $-13.725^{\star}$ & $20.833^{*}$ \\
\hline P1 x P5 & -1.28 & $-10.769^{\star}$ & 4.00 & -8.696 & -10.811 & $28.125^{\star \star}$ \\
\hline P2 $x$ P3 & $17.43^{\star \star}$ & -7.246 & -3.448 & -11.765 & 9.333 & 6.25 \\
\hline P2 X P4 & $38.03^{\star *}$ & $10.526^{*}$ & $-27.536^{\star *}$ & 12.821 & 0 & 6.25 \\
\hline P2 x P5 & $33.33^{\star *}$ & 7.692 & $-32.867^{* *}$ & $14.458^{*}$ & 11.712 & 2.083 \\
\hline P3 $\times$ P4 & -4.06 & -5.797 & $-16.564^{\star *}$ & 11.765 & 9.705 & -0.926 \\
\hline P3 x P5 & -3.73 & -6.521 & -2.381 & 1.176 & 7.451 & -6.349 \\
\hline P4 x P5 & $20.15^{* *}$ & $18.797^{* *}$ & $-14.286^{*}$ & 10.843 & 8.547 & -0.926 \\
\hline $\mathrm{P} 2 \times \mathrm{P} 1$ & $14.59^{* \star}$ & 0.952 & -1.316 & $-16.304^{\star *}$ & -6.25 & 6.25 \\
\hline P3 x P1 & -4.53 & $-15.942^{\star *}$ & 9.605 & $-13.043^{*}$ & $14.667^{*}$ & 0 \\
\hline P4 x P1 & $26.89^{* *}$ & $13.534^{* *}$ & $-14.118^{*}$ & 5.435 & $-18.627^{\star *}$ & $26.042^{\star *}$ \\
\hline P5 x P1 & 7.23 & -3.077 & 4 & -8.696 & 8.108 & 6.25 \\
\hline P3 x P2 & $22.02^{\star *}$ & -3.623 & $-31.034^{* *}$ & 11.765 & -8.444 & $27.083^{* \star}$ \\
\hline P4 x P2 & $42.72^{\star * *}$ & $14.286^{\star *}$ & $-46.377^{* *}$ & $29.487^{* *}$ & -6.863 & 13.542 \\
\hline P5 x P2 & $21.91^{* *}$ & -1.538 & -11.888 & -3.614 & -10.811 & $28.125^{\star \star}$ \\
\hline P4 x P3 & $18.08^{* *}$ & $15.94^{* *}$ & -9.202 & 4.706 & $18.987^{\star \star}$ & -11.112 \\
\hline P5 x P3 & -5.22 & -7.97 & -10.714 & 9.412 & 5.098 & -3.968 \\
\hline P5 x P4 & -3.42 & -4.51 & 8.075 & -10.843 & 8.547 & -0.926 \\
\hline
\end{tabular}

$\mathrm{MP}=$ Heterosis over mid parent and $\mathrm{BP}=$ Heterosis over better parent.

*, ${ }^{* *}$ Significant at 0.05 and 0.01 levels of probability, respectively

Table 6. Heterosis percentage relative to the mid and better-parents of the $\mathrm{F} 1$ crosses and its reciprocal for fruit yield and quality traits

\begin{tabular}{|c|c|c|c|c|c|c|c|c|}
\hline \multirow{2}{*}{$\begin{array}{c}\text { Genotypes } \\
\text { Crosses } \\
\end{array}$} & \multicolumn{2}{|c|}{ No. of fruit/plant } & \multicolumn{2}{|c|}{ Fruit weight } & \multicolumn{2}{|c|}{ Fruit yield / plant } & \multicolumn{2}{|c|}{ T.S.S. } \\
\hline & $\mathbf{H} \% \mathbf{M p}$ & H\% Bp high & H \% Mp & H\% Bp high & $\mathbf{H} \% \mathbf{M p}$ & H\% Bp high & $\mathbf{H} \% \mathbf{M p}$ & H\% Bp high \\
\hline P1 x P2 & $14.711^{* *}$ & $-27.324^{\star *}$ & -2.988 & 2.735 & 12.159 & $-25.002^{*}$ & $-23.404^{\star *}$ & $16^{\star *}$ \\
\hline P1 x P3 & 0.091 & $26.479 * *$ & -6.866 & 4.335 & -3.304 & -18.393 & 5.574 & $-20^{\star *}$ \\
\hline P1 x P4 & $-17.206^{\star *}$ & $-13.333^{*}$ & -6.41 & -3.669 & $-29.682^{\star *}$ & 3.16 & $8.108^{* *}$ & $-20.468^{* *}$ \\
\hline P1 x P5 & $32.143^{\star *}$ & $-46.478^{* *}$ & -8.681 & 5.125 & $27.098^{*}$ & $-43.996^{\star *}$ & $-17.409^{\star *}$ & $16^{\star *}$ \\
\hline P2 x P3 & $-25.056^{\star *}$ & 11.3 & 1.321 & -3.427 & -23.215 & 12.101 & $19.310^{* *}$ & $-35^{\star *}$ \\
\hline P2 X P4 & $-59.524^{* *}$ & 3 & -11.425 & 1.094 & $-82.534^{* *}$ & 67.4 & -2.491 & $-15.789^{* *}$ \\
\hline P2 x P5 & -12 & 2. & $-30.016^{* *}$ & $25.464^{* *}$ & -46 & 29. & $-12.069^{* *}$ & 6.557 \\
\hline P3 x P4 & -9.589 & 2.564 & $-14.160^{*}$ & 5.648 & -25.62 & 24.449 & $20.227^{\star *}$ & $-22.222^{* *}$ \\
\hline P3 x P5 & $-38.125^{\star *}$ & $34.756^{\star *}$ & 0.661 & -6.109 & $-37.845^{\star}$ & 32.67 & $-11.921^{* *}$ & $-6.111^{*}$ \\
\hline P4 x P5 & & & -6.498 & & $-36.990^{*}$ & & $-9.898^{* *}$ & $-5.848^{*}$ \\
\hline \multicolumn{9}{|l|}{ Reciprocal } \\
\hline & -10.7 & $r$ & $-25.790^{\star *}$ & $25.481^{* *}$ & -39. & & $-25.957^{* *}$ & $18.4^{\star *}$ \\
\hline P3 x P1 & -33.08 & & 0.123 & -2.488 & $-33.763^{* *}$ & & $-17.377^{\star *}$ & -0.556 \\
\hline P4 x P1 & 37.1 & $-53.521^{* *}$ & $-25.406^{\star *}$ & 13.528 & 18.309 & $-35.0165^{\star *}$ & $-14.865^{\star *}$ & -0.585 \\
\hline P5 x P1 & $-14.946^{\star}$ & -9.338 & $-20.490^{\star}$ & 16.548 & $-38.036^{* *}$ & 6.039 & $-31.984^{\star *}$ & $30.4^{\star \star}$ \\
\hline P3 x P2 & 11.011 & $-20.8^{* *}$ & -8.883 & 6.6 & 2.169 & -10.992 & 2.759 & $-21.667^{* *}$ \\
\hline P4 x P2 & $16.071^{*}$ & -29 . & -12.471 & 2.043 & 3.401 & -11.362 & $-8.185^{\star *}$ & $-11.111^{\star *}$ \\
\hline P5 x P2 & $-18.681^{*}$ & 7.9 & -12.362 & 8.428 & $-34.409^{\star}$ & 18.151 & -5.172 & 0 \\
\hline P4 x P3 & 8.082 & -13.974 & $16.948^{*}$ & $-23.140^{\star *}$ & 23.811 & -24.521 & $-8.832^{\star *}$ & $6.112^{*}$ \\
\hline P5 x P3 & $31^{* *}$ & $-32.682^{\star *}$ & -0.136 & -5.357 & 30.405 & -33.017 & $5.960^{*}$ & $-21.112^{\star *}$ \\
\hline P5 x P4 & $-25.333^{\star *}$ & 14.634 & -6.015 & -6.838 & $-36.406^{*}$ & 30.108 & $-20.819^{* *}$ & 3.509 \\
\hline
\end{tabular}

$\mathrm{MP}=$ Heterosis over mid parent and $\mathrm{BP}=$ Heterosis over better parent.

*, ** Significant at 0.05 and 0.01 levels of probability, respectively 

Complete Diallel Crosses among Five Inbred Lines of Cucumber

As to TSS\%, twelve and five crosses exhibited significant positive heterotic effects relative to $\mathrm{Mp}$ and $\mathrm{Bp}$, respectively. The most desirable heterotic effects were detected by crosses P1xP2, P1xP5, $\mathrm{P} 2 \times \mathrm{P} 1, \mathrm{P} 5 \mathrm{xP} 1$ and $\mathrm{P} 4 \mathrm{xP} 3$ which gave useful heterosis relative to $\mathrm{Mp}$ and $\mathrm{Bp}$. Similar results on cucumber were also reported by $\mathbf{Q i}$ and Chui (1991), Vijyakumari et al (1993), Li et al (1995), Cramer and Wehner (1999), Bairagi et al (2002), and Singh et al (2014) on vine length, fruit length, fruit diameter, number of fruits per plant and fruit yield per plant heterosis, vas worked out as percentage deviation of the F1 mean over mid-parent and better parent in each cross for all the traits and their significant relative heterosis.
Potency ratio: The potency ratio of the tested twenty crosses for seven studied traits is shown in Table 7. The plant length appeared partial dominance in the seven crosses P1 x P3, P1 x P5, P2 $x$ P3, P3 x P1, P5 x P1, P3 x P2 and P5 x P2. These seven crosses showed over dominance towards the longer parent, i.e. P1 x P2, P4 x P5, P4 x P1, P3 $x$ P2, P4 x P2, P5 x P3 and P5 x P4. Meanwhile, the remain crosses showed over dominance towards the short parent. Concerning the number of leaves per plant, 13 crosses showed over dominance, five of them were over toward the high parent, i.e. P3 $\times$ P4, P3 $x$ P5, P3 $\times$ P1, P3 $x$ P2 and $\mathrm{P} 4 \times \mathrm{P} 2$. But the remaining crosses showed partial dominance.

Table 7. The potence ratio of $\mathrm{F} 1$ crosses and reciprocal for all studied traits

\begin{tabular}{|c|c|c|c|c|c|c|c|}
\hline Genotype & $\begin{array}{l}\text { Plant } \\
\text { length }\end{array}$ & $\begin{array}{c}\text { No. } \\
\text { leaves/ } \\
\text { Plant }\end{array}$ & $\begin{array}{c}\text { No. of days } \\
\text { to } 1^{\text {st }} \text { har- } \\
\text { vest }\end{array}$ & $\begin{array}{c}\text { No. of } \\
\text { fruit/Plant }\end{array}$ & Fruit weight & $\begin{array}{c}\text { Fruit } \\
\text { yield/plant }\end{array}$ & T.S.S. \\
\hline \multicolumn{8}{|l|}{ Crosses } \\
\hline P1 x P2 & 1.16 & 0.25 & 0.00 & -3.00 & -12.15 & -0.71 & 3.67 \\
\hline P1 x P3 & 0.03 & -3.29 & -0.09 & -3.00 & -2.83 & 0.12 & 0.31 \\
\hline P1 x P4 & -1.86 & -0.57 & -2.33 & -5.00 & -0.61 & 1.15 & 0.52 \\
\hline P1 x P5 & 0.12 & -0.78 & -0.80 & -1.00 & 2.57 & -0.90 & 14.33 \\
\hline P2 x P3 & -0.66 & -0.20 & 0.64 & -3.00 & 0.61 & 2.34 & 0.80 \\
\hline P2 X P4 & -1.53 & -2.11 & 0.00 & 0.00 & -1.12 & 9.19 & -0.11 \\
\hline P2 x P5 & -1.40 & -2.04 & 0.87 & -1.00 & 8.27 & 3.41 & -2.33 \\
\hline P3 x P4 & -2.20 & 3.86 & -1.10 & 3.00 & -1.76 & -27.22 & -7.89 \\
\hline P3 x P5 & -1.25 & 2.00 & -6.33 & -3.00 & -0.11 & 9.70 & 0.62 \\
\hline P4 x P5 & 17.67 & -4.60 & 1.11 & -2.00 & 0.47 & 7.64 & 0.59 \\
\hline \multicolumn{8}{|l|}{ Reciprocal } \\
\hline $\mathrm{P} 2 \times \mathbf{P 1}$ & -1.08 & -0.06 & 0.00 & 1.00 & 105.40 & -2.31 & -4.07 \\
\hline P3 x P1 & -0.33 & 2.43 & -1.00 & 0.00 & -0.05 & -1.27 & 0.96 \\
\hline P4 x P1 & 2.29 & -1.71 & 3.17 & 7.00 & 2.43 & 0.71 & 0.96 \\
\hline P5 x P1 & 0.68 & 0.78 & -0.60 & 1.00 & -6.06 & -1.26 & -26.33 \\
\hline P3 x P2 & 0.83 & 1.80 & 0.58 & 1.00 & 4.07 & 0.22 & -0.11 \\
\hline P4 x P2 & 1.72 & 3.56 & 1.17 & 0.00 & 1.22 & 0.38 & 0.38 \\
\hline P5 x P2 & 0.92 & 0.74 & 0.80 & 1.00 & -3.41 & -2.50 & 1.00 \\
\hline P4 x P3 & -9.80 & -2.14 & 2.14 & -5.00 & -2.10 & -25.30 & -3.44 \\
\hline P5 x P3 & 1.75 & -9.00 & 4.33 & 3.00 & -0.02 & 7.79 & 0.31 \\
\hline P5 x P4 & 3.00 & -2.60 & -1.11 & 2.00 & -0.44 & -7.52 & -1.24 \\
\hline
\end{tabular}




\section{Estimate of Some Genetic Parameters for Some Vegetative and Yielding Traits in}

Complete Diallel Crosses among Five Inbred Lines of Cucumber

Concerning the number of days to the first harvest, two crosses $\mathrm{P} 1 \mathrm{x} \mathrm{P} 2$ and its reciprocal $\mathrm{P} 2 \mathrm{x}$ $\mathrm{P} 1$, as well as the cross P2x P4, exhibited an absence of dominance. On the other hand, the cross P3x P1 showed a complete dominance. Seven crosses, i.e P1 x P3, P1 x P5, P2 x P3, P2 x P5, $\mathrm{P} 5 \times \mathrm{P} 1, \mathrm{P} 3 \times \mathrm{P} 2$ and P5 $\times \mathrm{P} 2$ showed a partial dominance. Meanwhile, the remain crosses showed over dominance

With respect to number of fruits per plant, the 13 crosses P1 x P5, P2 x P3, P2 x P4, P2 x P5, P3 $\times \mathrm{P} 4, \mathrm{P} 3 \times \mathrm{P} 5, \mathrm{P} 4 \times \mathrm{P} 5, \mathrm{P} 3 \times \mathrm{P} 1, \mathrm{P} 4 \times \mathrm{P} 1, \mathrm{P} 5 \times \mathrm{P} 2$, $\mathrm{P} 4 \times \mathrm{P} 3, \mathrm{P} 5 \times \mathrm{P} 3$ and P5 $\times$ P4 presented over dominance. However, the remaining crosses showed a partial dominance for this trait.

As for as fruit weight, partial dominance was detected in crosses P1 x P4, P2 x P3, P3 x P5, P4 $x$ P5, P3 x P1, P5 x P3 and P5 x P4. However, the remaining crosses showed over dominance for this trait.

Regarding to fruit yield/ plant, six crosses $\mathrm{P} 1 \mathrm{x}$ $\mathrm{P} 2, \mathrm{P} 1 \times \mathrm{P} 3, \mathrm{P} 1 \times \mathrm{P} 5, \mathrm{P} 4 \times \mathrm{P} 1, \mathrm{P} 3 \times \mathrm{P} 2$ and $\mathrm{P} 4 \times$ $\mathrm{P} 2$ displayed a partial dominance however, the remaining crosses showed over dominance for this trait.

With respect to TSS \%, the cross P5 $\times$ P2 showed a complete dominance. Meanwhile, the crosses $\mathrm{P} 1 \times \mathrm{P} 2, \mathrm{P} 1 \times \mathrm{P} 5, \mathrm{P} 2 \times \mathrm{P} 5, \mathrm{P} 3 \times \mathrm{P} 4, \mathrm{P} 2 \times$ $\mathrm{P} 1, \mathrm{P} 5 \times \mathrm{P} 1, \mathrm{P} 4 \times \mathrm{P} 3$ and $\mathrm{P} 5 \times \mathrm{P} 4$ showed over dominance. However the other crosses showed partial dominance. Similar findings were reported by Sirohi et al (2002), Jha et al (2009), Gharib et al (2014) and El-Tahawey et al (2015).

\section{REFERECES}

Bairagi S.K., Singh D.K. and Ram H.H. 2002. Studies of heterosis for yield attributes in cucumber (Cucumis sativus L.) 29(1), 75-77.

Chawla H.S. and Gupta V.P. 1984. Index IndiaAgric. Calcutta Agric. Soc. Indian, 28(4), 261265.

Cockerham C.C. 1963. Estimation of genetic variances. In: HANSON, W.D.; ROBINSON, H.F. (ed.) Statistical genetics and plant breeding. Washington: National Academy of Science, 1963. pp. 53-94.

Cremar C.S. and Wehner T.C. 1991. Little heterosis for yield and yield components in hybrid of six cucumber inbrids. 110(02), 99-108.

Darwish N.M.S. 1992. Genetical studies on some cucumber hybrids (Cucumis sativus L.). Ph.D. thesis, Faculty of Agric., Zagazig Univ., Zagazig, Egypt. 97 p.

Das S., Maurya K.R. and Choudhary D.N. 2003. Heritability studies in cucumber. J. App. Bio. 13(1\&2), 54-57.

El-Hosary A.A.A, Motawea M.H. and Elgammaal A.A. 2018. Combining ability for yield and some of its attributes in maize across two locations. 22(3), 625- 640.

El-Hosary A.A.A. 2014. Comparison between some methods of diallel cross analysis in maize. Egypt. J. Plant Breed., 18(4), 715-736.

El-Hosary, A.A.A., Sedhom A.S. and El-Badawy M.EL.M. 2011. Genetic and Biotechnological Studies for Important Traits in Maize. LAP Lambert Academic Publishing, ISBN 978-38454-4108-5, paperback, 280 p.

El-Mahdy I.M., Mazrouh A.Y. and Gendy A.S. 1992. Heterosis and nature of gene action in intervarietal crosses of cucumber (Cucumis sativus L.) Menofiya J. Agric. Res., 17(3), 12511261.

El-Tahawey M.A.F.A. Kandeel A.M., Youssefy S.M.S. and Abd EI-Salam M.M.M. 2015. Heterosis, potence ratio, combining ability and correlation of some economic traits in diallel crosses of pumpkins. Egypt. J. Plant Breed. 19(2), 419-439. Doi: 10.12816/0011721.

Engels D., Sinzinkayo E. and Gryseels B. 1996. Day-to-day egg count fluctuation in Schistosoma mansoni infection and its operational implications. American J. of Tropical Medicine and Hygiene, 54, $319-324$.

FAO, 2015. FAOSTAT. Food and Agriculture Organization.

Gharib A.A. 1991. Evaluation of F1 hybrid cucumber cultivars under plastic house conditions for some economic characters using diallel analysis. M.Sc. thesis, Cairo Univ., Cairo, Egypt, $112 \mathrm{p}$.

Gharib A.H., El-Gizawy A.M., El-Miniawy S.M. and Abdelsalam M.M. 2014. Utilization of heterosis in the development of some traits in pumpkin. Egypt. J. of Appl. Sci. 29(10), 482 493.

Gomez K.A. and Gomez A.A. 1984. Statistical analysis procedures for agricultural research. New York, NY: John Wiley and Sons. pp. 2530.

Griffing B. 1956. Concept of general and specific combining ability in relation to diallel crossing systems. Aus. J. of Biol. Sci., 9, 463-493. 
Hanchinamani C.N., Patil M.G., Dharmatti P.R. and Mokashi A.N. 2008. Studies on variability in cucumber (Cucumis sativus L.). Crop Res. 36(1\&3), 273-276.

Jha A., Pandey S., Rai M., Yadav D.S. and Singh T.B. 2009. Heterosis in relation to combining ability for flowering behaviors and yield parameters in pumpkin. Veg. Sci. 36 (3 suppl.), 332333.

Kumar A. 2006. Studies on heterosis and inheritance of resistance to fruit fly in cucumber ( $\mathrm{Cu}$ cumis sativus L.). Ph.D. Thesis, Dr. Y.S. Parmar University of Horticulture and Forestry, India, $109 \mathrm{p}$.

Kumar A., Kumar S. and Pal A.K. 2008. Genetic variability and characters association for fruit yield and yield traits in cucumber. Indian $\mathbf{J}$. Hort. 65(4), 423-428.

Kumar S., Kumar D., Kumar R., Thakur K.S. and Dogra B.S. 2013. Estimation of Genetic Variability and Divergence for Fruit Yield and Quality Traits in Cucumber (Cucumis Sativus L.) in North-Western Himalays. Universal J. of Plant Sci., 1(2), 27-36.

Li J.W., Li J.W. and Zhu D.W. 1995. Genetic analysis of major agronomic characters in $\mathrm{Cu}$ cumber (Cucumis sativus L.). ActaHorticulturae, 402, 388-391.

Lonnquit J.H. and Gardner C.D. 1961. Heterosis in intervarietal crosses in maize and its implications in breeding procedures. Crop Sci. 1, 179183.

Mather K. and Jinks J.L. 1971. Biometrieal genetics, $2^{\text {nd }}$ Edn. Chapman \& Hall, London, UK, $66 \mathrm{p}$.

Matzinger D.F. and Kempthorne O. 1956. The modified diallel Table with partial inbreeding and interactions with environment. Genetics, 41(1), 822-833.

Munshi A.D., Panda B., Behera T.K., Kumar R., Bisht I.S. and Behera T.K. 2007. Genetic variability in Cucumis sativus var. hardwickii $\mathrm{R}$. germplasm. Cucurbit Genet. Coop. 30, 5-10.

Olfati J.A. Samizadeh H., Rabiei B. and Peyvast G.H. 2012. Griffing's Methods Comparison for General and Specific Combining Ability in $\mathrm{Cu}$ cumber. The Scientific World J., 2012, 1-4. ID 524873, 4 p. doi:10.1100/2012/524873.

Pitrat M., Chauvet C. and Foury C. 1999. Diversity, history and production of cultivated Cucurbits. Acta Horticulturae 492, 21-28.

Qi Y.T. and Chui H.W. 1991. Studies on early maturity heterosis and its formative basis of yield component traits in cucumber (Cucumis sativus L.). Acta-Horticulturae Sinica, 18(4), 330-334.

Sandeep K., Kumar D., Kumar R., Thakur K.S. and Dogra B.S. 2013. Estimation of Genetic Variability and Divergence for Fruit Yield and Quality Traits in Cucumber (Cucumis Sativus L.) in North-Western Himalays Universal J. of Plant Sci. 1(2), 27-36.

Sedhom A.S., El-Badawy M.El.M., Morsy A.M. and El-Hosary A.A.A. 2007. Diallel analysis and relationship between mollecular polymorphisms and yellow maize hyprid performance. Annals of Agric. Sci., Moshtohor. 45(1), 120.

Singh M. 1997. Variability studies in some lines of cucumber (Cucumis sativus L.). M.Sc. Dr. Y.S. Parmar University of Horticulture and Forestry, India, 99 p.

Singh R.V., Verma T.S. and Thakur P.C. 2002. Characters association in cucumber. Haryana J. Hort. Sci., 31(1\&2), 91-93.

Sirohi P.S., Reddy Y.S. and Behera T.K. 2002. Heterosis for yield and its attributing traits in pumpkin (Cucurbita moschata Duch. ex Poir.). Veg. Sci. 29(2), 178-179.

Smith H.H. 1952. Fixing Transgressive Vigor in Nicotiana Rustica. lowa State College Press, Ames, USA., 552 p.

Solanki S.S. and Seth J.N. 1980. Studies on genetic variability in cucumber (Cucumis sativus L.). Progressive Horticulture, 12(1), 43-49.

Sprague G.F. and Tatum L.A. 1942. General vs specific combining ability in single crosses of corn. J. Am. Soc. Agron. 34, 923-932.

Singh S.K., Singh, S.V. and Srivastava J.P. 2014. Heterosis and inbreeding depression for yield and its component traits in cucumber. Agriways 2(1), 47-51.

Verma S. 2003. Genetic variability and correlation studies in cucumber (Cucumis sativus L.). M. Sc. Dr. Y.S. Parmar University of Horticulture and Forestry, India, 61 p.

Vijayakumari P., More T.A. and Seshadri V.S. 1993. Heterosis in tropical and temperate gynoecious hybrids in cucumber. Veg. Sci., 20(2), 152-157.

Waller R.A. and Duncan D.B. 1969. "A Bayes Rule for the Symmetric Multiple Genotypes for Yield and its Contributing Traits under Mid-Hill Conditions of Himachal Pradesh, India 67(2), 202-205.

Wadid M.M., Medany M.A. and Abou-Hadid A.F. 2003. Diallel analyses for yield and vegetative characteristics in cucumber (cucumis sativus 
Estimate of Some Genetic Parameters for Some Vegetative and Yielding Traits in

Complete Diallel Crosses among Five Inbred Lines of Cucumber

L.) under low temperature conditions. ISHS Acta-Hort. 598 p.

Yacoup H.M., Abd El-sabour, S.F., Mahmoud S.H., Hassan M.N. and Gad El-Hak S.H. 1993. Diallel analysis of some economic characters in cucumber. Minia $1^{\text {st }}$ Conf. for Hort. Crops, pp. 409- 430.

Yogesh C., Yadav S.K., Brijpal B. and Dixit S.K. 2009. Genetic variability, heritability and genetic advance for some traits in cucumber. Indian J. Hort. 66(4), 488-491. 
$14^{\text {th }}$ Conf. Agric. Develop. Res., Fac. of Agric., Ain Shams Univ.,

March, 2019, Cairo, Egypt

Special Issue, 27(1), 635 - 648, 2019

Website: http://strategy-plan.asu.edu.eg/AUJASCI/

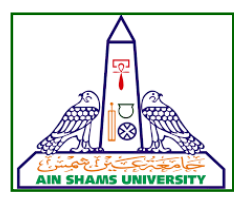

635

تقديرات وراثية لبعض الصفات الخضرية وإمحصولية بالتهجين الكامل

لخمس سلالات من الخيار

[59]

عمر عبدالله محمود جادالله"- صلاح محمود المنياوى - سلامة عبد الحميد عبد الهادى-

إبراهيم ابراهيم العكش صنش

قسم البساتين- كلية الزراعة- جامعة عين شمس- ص.ب 68 - حدائق شبرا 11241 - القاهرة - مصر

${ }^{*}$ Corresponding author: omar.abd-alla@hytechseed.com

Received 22 September, 2018, Accepted 14 October, 2018

السائدة والمضيفة فى توريث هذه الصفات.

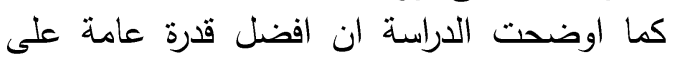

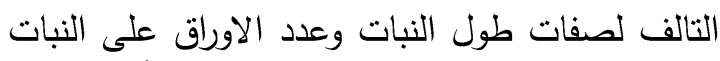

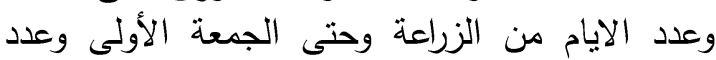

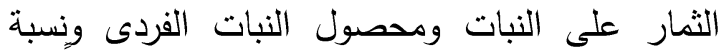

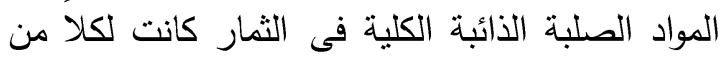

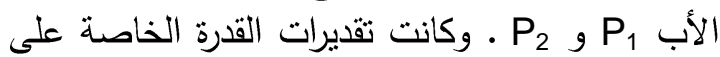
التآلف أعلى لكلأ من الهجن

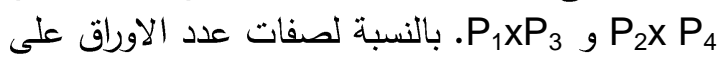
النبات وعدد الايام من الزراعة وحتى الجمعة الاولى الألى ومحصول النبات الفردى. وكذاللك افضل قدرة خاصة الفئ على التألف للهجن العكسية P بالنسبة لصفة المحصول للنبات $P_{4} x P_{1}, P_{4} x P_{2}$ الفردى.

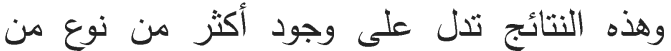

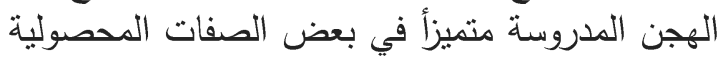

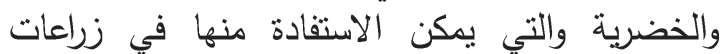

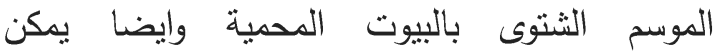
استخدامها فى تحسين وتطويربرامج التربية المستقبليه

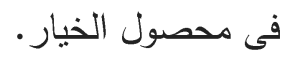

الكلمات الدالة: الخيار، قوة الهجين، درجة السيادة، القدرة على التألف، الفعل الاضافى للجين التين

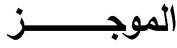

تم تقييم عشرون هجينا مع ابائها من محصول

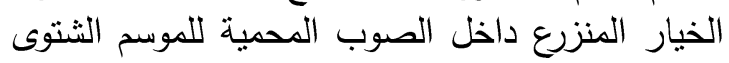
2014 و 2015 وهذه الهجن ناتجة من التلتيح الائرى الكامل لخمس سلالات مرباه داخليا وذللك ناته بمحطة ابحاث شركة مصر هاى تلك الدولية للبذور

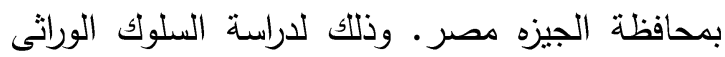

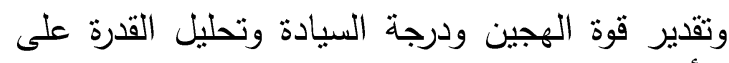

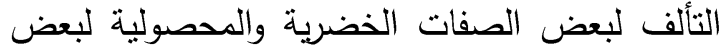

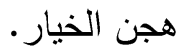

حيث أظهرت الهجن مدى من قوة الهجين بالنسبة

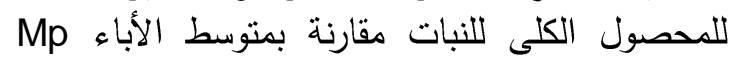

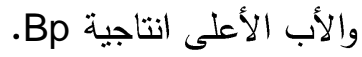

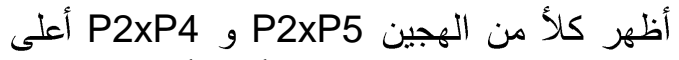
قوة هجين مقارنة بمتوسط الآباء والأب الأعلى انتاجية.

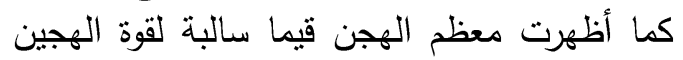

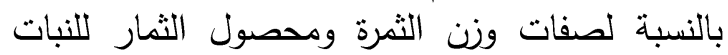

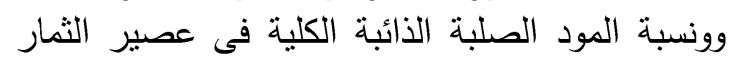
عندما قدرت بالنسبة لمتوسط الأباء والأب الأبة الأعلى لئل

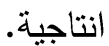
كانت التباينات الناتجة عن القدرة العامة والقدرة

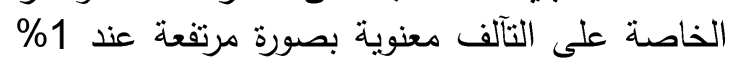
للصفات تحت الدراسة وهذا يدل على اثتراك العوامل 